\title{
Organic anion transporting polypeptides of the OATP/ SLC21 family: phylogenetic classification as OATP/ SLCO superfamily, new nomenclature and molecular/functional properties
}

\author{
Hagenbuch, Bruno ; Meier, Peter J
}

\begin{abstract}
The organic anion transporting polypeptides (rodents: Oatps, human: OATPs) form a superfamily of sodium-independent transport systems that mediate the transmembrane transport of a wide range of amphipathic endogenous and exogenous organic compounds. Since the traditional SLC21 gene classification does not permit an unequivocal and species-independent identification of genes and gene products, all Oatps/OATPs are newly classified within the OATP/SLCO superfamily and subdivided into families ( $40 \%$ amino acid sequence identity), subfamilies ( $60 \%$ amino acid sequence identity) and individual genes and gene products according to their phylogenetic relationships and chronology of identification. Implementation of this new classification and nomenclature system occurs in agreement with the HUGO Gene Nomenclature Committee (HGNC). Among 52 members of the OATP/SLCO superfamily, 36 members have been identified so far in humans, rat and mouse. The latter are clustered within 6 (out of 12) families (OATP1-OATP6) and 13 subfamilies. Oatps/OATPs represent 12 transmembrane domain proteins and contain the superfamily signature D-X-RW-(I,V)-GAWW-X-G-(F,L)-L. Although species divergence, multispecificity and wide tissue distribution are common characteristics of many Oatps/OATPs, some members of the OATP/SLCO superfamily are highly conserved during evolution, have a high substrate specificity and exhibit unique cellular expression in distinct organs. Hence, while Oatps/OATPs with broad substrate specificity appear to play an important role in the bioavailability, distribution and excretion of numerous exogenous amphipathic organic anionic compounds, Oatps/OATPs with a narrow spectrum of transport substrates may exhibit more specific physiological functions in distinct organs
\end{abstract}

DOI: https://doi.org/10.1007/s00424-003-1168-y

Posted at the Zurich Open Repository and Archive, University of Zurich

ZORA URL: https://doi.org/10.5167/uzh-156363

Journal Article

Published Version

Originally published at:

Hagenbuch, Bruno; Meier, Peter J (2004). Organic anion transporting polypeptides of the OATP/ SLC21 family: phylogenetic classification as OATP/ SLCO superfamily, new nomenclature and molecular/functional properties. Pflügers Archiv : European Journal of Physiology, 447(5):653-665.

DOI: https://doi.org/10.1007/s00424-003-1168-y 


\section{Organic anion transporting polypeptides of the 0ATP/SLC21 family: phylogenetic classification as OATP/SLCO superfamily, new nomenclature and molecular/functional properties}

Received: 8 May 2003 / Revised: 9 August 2003 / Accepted: 15 August 2003 / Published online: 25 October 2003 (C) Springer-Verlag 2003

\begin{abstract}
The organic anion transporting polypeptides (rodents: Oatps, human: OATPs) form a superfamily of sodium-independent transport systems that mediate the transmembrane transport of a wide range of amphipathic endogenous and exogenous organic compounds. Since the traditional SLC21 gene classification does not permit an unequivocal and species-independent identification of genes and gene products, all Oatps/OATPs are newly classified within the OATP/SLCO superfamily and subdivided into families $(\geq 40 \%$ amino acid sequence identity), subfamilies ( $\geq 60 \%$ amino acid sequence identity) and individual genes and gene products according to their phylogenetic relationships and chronology of identification. Implementation of this new classification and nomenclature system occurs in agreement with the HUGO Gene Nomenclature Committee (HGNC). Among 52 members of the OATP/SLCO superfamily, 36 members have been identified so far in humans, rat and mouse. The latter are clustered within 6 (out of 12) families (OATP1-OATP6) and 13 subfamilies. Oatps/OATPs represent 12 transmembrane domain proteins and contain the superfamily signature D-X-RW-(I,V)-GAWW-X-G(F,L)-L. Although species divergence, multispecificity and wide tissue distribution are common characteristics of many Oatps/OATPs, some members of the OATP/SLCO superfamily are highly conserved during evolution, have a high substrate specificity and exhibit unique cellular expression in distinct organs. Hence, while Oatps/OATPs with broad substrate specificity appear to play an important role in the bioavailability, distribution and excretion of numerous exogenous amphipathic organic anionic compounds, Oatps/OATPs with a narrow spec-
\end{abstract}

\footnotetext{
B. Hagenbuch $(\varangle) \cdot$ P. J. Meier

Division of Clinical Pharmacology and Toxicology,

Department of Medicine,

University Hospital,

8091 Zurich, Switzerland

e-mail: Bruno.Hagenbuch@access.unizh.ch

Tel.: +41-1-6343151

Fax: +41-1-2554411
}

trum of transport substrates may exhibit more specific physiological functions in distinct organs.

Keywords Bile salt · Drug transporter $\cdot$ Xenobiotic elimination

\section{Introduction}

Organic anion transporting polypeptides (rodents: Oatps, human: OATPs) are important membrane transport proteins that mediate the sodium-independent transport of a wide range of amphipathic organic compounds including bile salts, organic dyes, steroid conjugates, thyroid hormones, anionic oligopeptides, numerous drugs and other xenobiotic substances [1]. Although some Oatps/ OATPs are selectively involved in the hepatic clearance of albumin-bound compounds from portal blood plasma [2], most Oatps/OATPs are expressed in multiple tissues including the blood-brain barrier (BBB), choroid plexus, lung, heart, intestine, kidney, placenta and testis [3]. Unfortunately, the rapid and independent identification of new Oatps/OATPs has led to the assignment of either different names for identical proteins or similar names for non-orthologous gene products [1]. Furthermore, the current classification within the solute carrier family 21 (rodents: Slc21; human: SLC21) does not permit an unequivocal and species-independent identification of the various Oatp/OATP-genes [1]. To solve these problems and to avoid further confusions in future scientific discussions, we have proposed a new species-independent classification and nomenclature system that is based on divergent evolution and defines an Oatp/OATP-gene superfamily, which can be divided further into families, subfamilies and individual genes and gene products according to the evolutionary relationships and the degree of amino acid sequence identities [1]. Meanwhile, the principle of this evolutionary-based new Oatp/OATP classification and nomenclature system has been welcomed and accepted by several experts in the field and, most importantly, also by the HUGO Gene Nomenclature 
Committee (HGNC). Since the current Slc21/SLC21 classification does not permit the sub-classification of the Oatp/OATP-gene superfamily into families and subfamilies as suggested in analogy to the cytochrome P450 superfamily [1, 4], and since the HGNC suggested to keep the root gene symbol " $S L C$ ", it has been agreed to create the new "SLCO" symbol for gene classification and to keep the "OATP" symbol for corresponding protein nomenclature. It is the main purpose of this overview to present the definite principles, rules and naming of the new OATP/SLCO classification and nomenclature system. Furthermore, comparative tables and figures are provided to help in the translation of the old into the new system. And finally, the history of discovery and the molecular and physiological properties of individual Oatps/OATPs will be summarized. Further details about the molecular and functional properties of this transporter superfamily can be found in our previous review [1].

\section{New classification and nomenclature}

So far 36 Oatps/OATPs have been identified in humans, rat and mouse (Fig. 1). As indicated in Table 1, most Oatps/OATPs have been given several different trivial names, and sometimes similar names have been used for different gene products in different species (e.g. rat Oatp1/human OATP1; rat Oatp2/mouse Oatp2/human OATP2). Furthermore, organ-specific rather than a functionally based nomenclature has been used despite incomplete knowledge about the organ topology of individual Oatps/OATPs (Table 1). Although the provisional use of continuous numbering of rodent Oatps, alphabetic ordering of human OATPs and gene classification within the Slc21/SLC21 system has helped in the clear-cut identification of a specific gene product in the past, this system permits neither unequivocal and speciesindependent protein and gene identifications nor the classification of the various Oatp/OATP genes within a separate transporter superfamily [1]. That all Oatps/ OATPs do indeed form a transporter gene superfamily is evidenced by the phylogenetic tree (Fig. 1) and its underlying amino acid sequence identities [1]. This OATP superfamily can be further subdivided into families and subfamilies in close analogy to the classification of drug-metabolizing enzymes $[4,5]$. Hence, Oatps/OATPs within the same family share $\geq 40 \%$ amino acid sequence identities and are designated by Arabic numbering, e.g. families OATP1, OATP2, OATP3, OATP4, OATP5 and OATP6 (Fig. 2). Individual subfamilies include Oatps/ OATPs with amino acid sequence identities $\geq 60 \%$ and are designated by letters, e.g. subfamilies OATP1A, OATP1B, OATP1C, OATP2A, OATP2B, OATP3A etc. If there are several individual gene products (proteins) within the same subfamily, additional continuous Arabic numbering based on the chronology of identification should be used, e.g. Oatp1a1, OATP1A2, Oatp1a3, etc. (Fig. 2).
While the above outlined classification principle has been accepted by several experts in the field (number of experts contacted: 16; positive responses: 8 ; negative responses: 0; no responses: 8) and by the HGNC, the latter suggested to keep the "SLC" symbol for gene identification and to use the functional "OATP" symbol for protein nomenclature. To follow this recommendation it was necessary to introduce a new gene symbol, since the $S L C 21$ stem is not compatible with an unambiguous family designation, e.g. the gene of the OATP1 family member OATP1A2 would become SLC211A2, which could be confused with a member of the (hypothetical) SLC211 gene family. This problem was solved by changing SLC21 into the new gene symbol "SLCO" $(\mathrm{O}=$ initial letter of OATP $)$, which classifies for example the gene of OATP1A2 unambiguously as SLCO1A2 (Figs. 2, 3). By this adaptation it is possible to use the same phylogenetically based, species-independent and open-ended classification/nomenclature system at both the protein and gene levels for all members of the OATP/ $S L C O$ superfamily [1], to stay within the $S L C$ transporter gene classification of the HUGO (http://www.gene.ucl. ac.uk/nomenclature/) and mouse (http://www.informatics. jax.org) gene nomenclature committees, and to keep the original and well-accepted functional OATP designation at the protein level.

The principles and consequences of the new OATP/ SLCO classification and nomenclature system are further illustrated in Figs. 2 and 3 \{Please note the change introduced in Fig. 3 (see legend) with respect to the classification of the families OATP6 and OATP10 as compared to our previous suggestion [1]\}. Furthermore, the old and new protein and gene nomenclatures are compared in Table 2 and Fig. 3 to help in the translation from the old into the new system. Unambiguous and species-independent classification and naming of newly identified proteins (genes) of the OATP/SLCO superfamily according to the new system must include: (1) the superfamily designation OATP (SLCO) (human members) or Oatp (Slco) (rodent members), (2) the family number, (3) the subfamily letter (capital letters for human members, small letters for rodent members), and (4) continuous Arabic numbering according to the chronology of protein (gene) identification. Human proteins (genes) are given in capitals [e.g. OATP1A2 (SLCO1A2)] (http://www.gene.ucl.ac.uk/nomenclature/), while rat and mouse proteins (genes) are indicated by an initial capital followed by small letters [e.g. Oatpla1 (Slcola1), Oatp7a1 (Slco7al)] (http://www.informatics.jax.org). For other animal species (e.g. farm animals such as cow, pig, cat, dog, chicken) the exact writing styles should follow the recommendations of the respective nomenclature committees (e.g. http://www.thearkdb.org/ nomenclature.html; for further links see http://www. gene.ucl.ac.uk/nomenclature/). Furthermore, if several splice variants of a given Slco/SLCO gene are known, the names of the resulting Oatps/OATPs should be followed by an underscore, the lower case letter " $\mathrm{v}$ " and 
Fig. 1 Phylogenetic tree of the human and rodent members of the OATP/SLCO superfamily using the traditional (old) protein nomenclature. Human OATPs are given in capitals (exception: OAT-K1 represents a rat protein). Rodent Oatps are written with an initial capital followed by small letters. To distinguish between rat and mouse proteins, all mouse Oatps are indicated by " $m$ ". The tree was calculated using the ClustalW program (http://www.ebi.ac.uk/clustalw/) and visualized using the program TREVIEW [54]

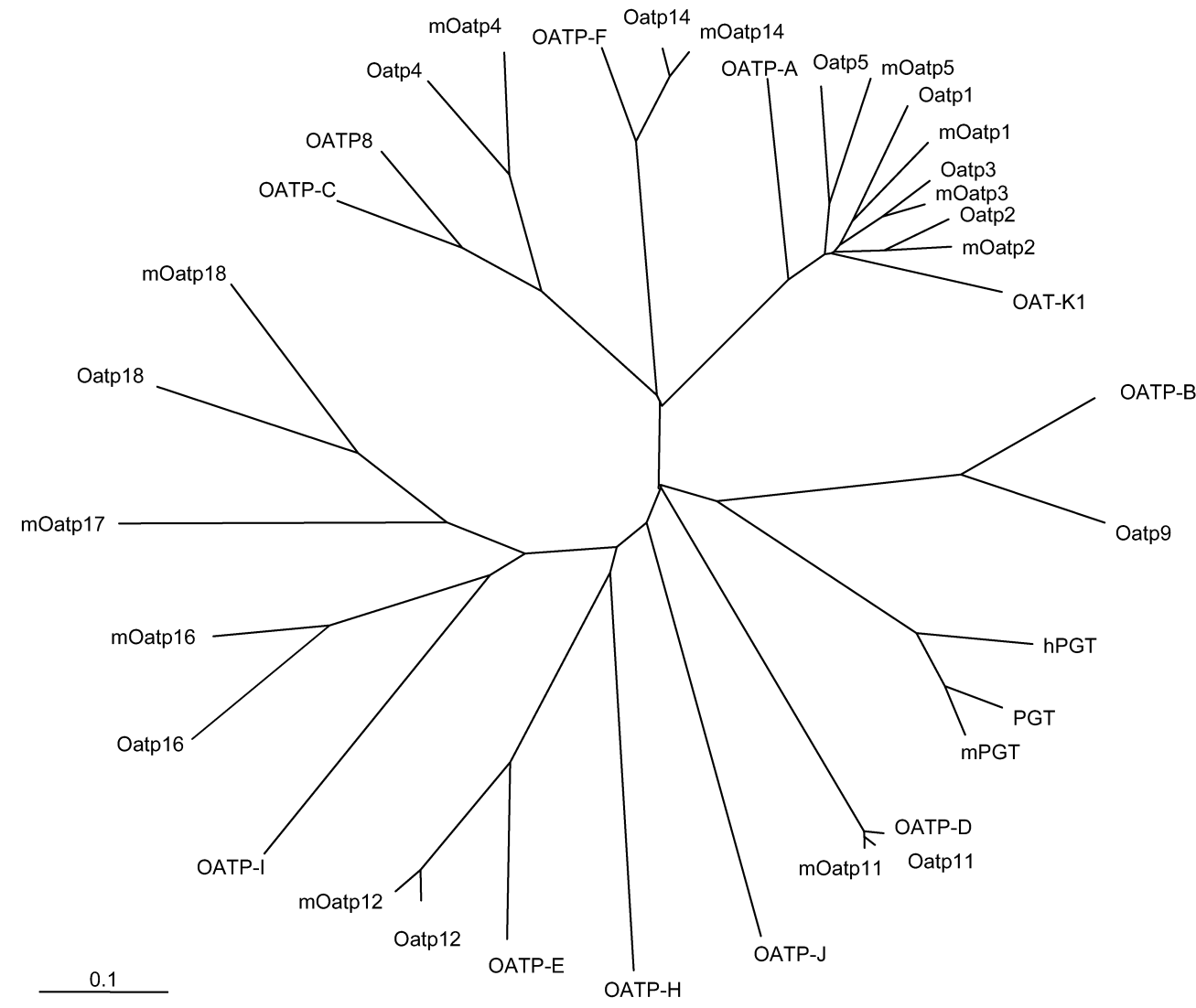

Table 1 Current Oatp/OATP protein and gene nomenclature and classification. Ambiguous protein names (e.g. similar names for distinct proteins, tissue specific names) are highlighted in bold. Abbreviations: BSAT, brain specific anion transporter; $G S T$, gonad specific transporter; lst/LST, liver specific transporter; MJAM, derived from the researchers initials; Oatp/OATP, organic anion transporting polypeptide; $P G T$, prostaglandin transporter; $S l c / S L C$, solute carrier; TST, testis-specific transporter

\begin{tabular}{|c|c|c|c|c|}
\hline $\begin{array}{l}\text { Protein } \\
\text { name }\end{array}$ & Alias & $\begin{array}{l}\text { Human gene } \\
\text { symbol }\end{array}$ & $\begin{array}{l}\text { Rat gene } \\
\text { symbol }\end{array}$ & $\begin{array}{l}\text { Mouse Gene } \\
\text { Symbol }\end{array}$ \\
\hline Oatp1 & Oatp & - & Slc21a1 & Slc2la1 \\
\hline PGT & hPGT (human), rPGT (rat), mPGT (mouse) & SLC21A2 & Slc $21 a 2$ & Slc21a2 \\
\hline OATP-A & OATP,OATP1 & $S L C 21 A 3$ & - & - \\
\hline OAT-K1 & & - $\quad$ & Slc21a4 & - \\
\hline Oatp2 & & - & Slc21a5 & Slc21a5 \\
\hline OATP-C & LST-1,OATP2, OATP6 & SLC21A6 & - & - \\
\hline Oatp3 & & - & Slc $21 a 7$ & Slc21a7 \\
\hline OATP8 & LST-2 & SLC21A8 & - & - \\
\hline OATP-B & OATP-RP2 (human), moat1 (rat), Oatp9 & SLC21A9 & Slc21a9 & - \\
\hline Oatp4 & rlst-1(rat),mlst-1(mouse) & - $\quad$ & Slc21a10 & Slc21a10 \\
\hline OATP-D & OATP-RP3 (human), Pgt2 (rat), MJAM(mouse), Oatp11 & $S L C 21 A 11$ & Slc21a11 & Slc21a11 \\
\hline OATP-E & OATP-RP1 (human), oatpE (rat), Oatp12 & $S L C 21 A 12$ & Slc21a12 & - \\
\hline Oatp5 & & - & Slc21a13 & Slc21a13 \\
\hline OATP-F & OATP-RP5 (human), BSAT1(rat), Oatp2(mouse), Oatp14 & SLC21A14 & Slc21a14 & Slc21a14 \\
\hline OATP-J & OATP-RP4 & SLC21A15 & - & - \\
\hline Oatp16 & TST-1, GST-1 & - & Slc21a16 & Slc21a16 \\
\hline Oatp17 & & - & - & Slc21a17 \\
\hline Oatp18 & TST-2, GST-2 & - & Slc21a18 & Slc21a18 \\
\hline OATP-I & GST & $S L C 21 A 19$ & - & - \\
\hline OATP-H & & $S L C 21 A 20$ & - & - \\
\hline
\end{tabular}

the consecutive numbering of the variants (e.g. Oatp1a3_v1, Oatp1a3_v2; Table 2).

The above outlined new classification system takes into account the molecular and phylogenetic relationships between individual genes and proteins, is easy to follow and provides an unambiguous open-ended species-independent nomenclature for all members of the OATP/ SLCO superfamily. Implementation of the new classifi- 


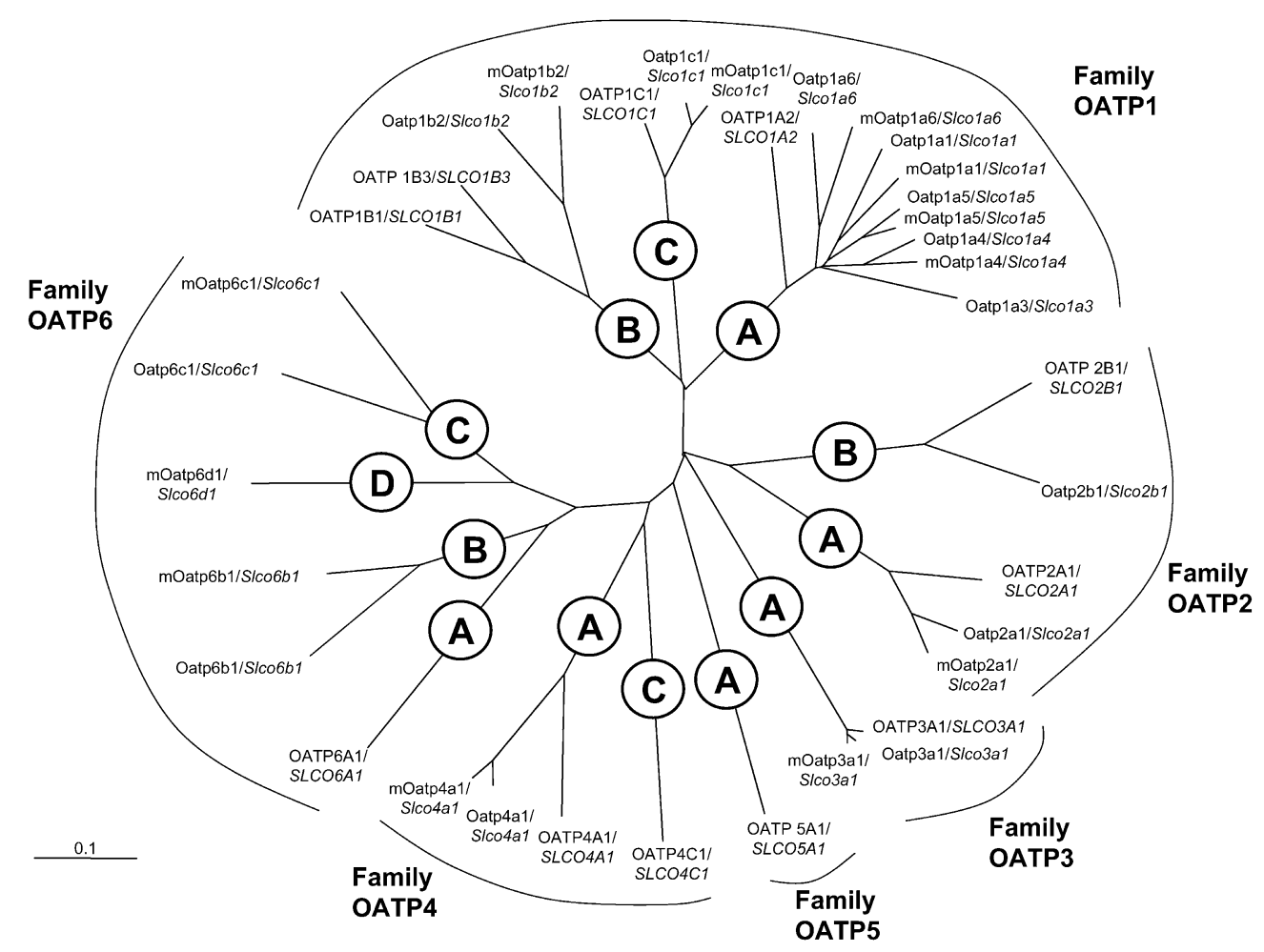

Fig. 2 Phylogenetic classification and new nomenclature of human and rodent (rat, mouse) members of the OATP/SLCO superfamily of membrane transporters. Oatps/OATPs with amino acid sequence identities $\geq 40 \%$ among each other belong to the same OATP family (e.g. OATP1, OATP2, OATP3, OATP4, OATP5, OATP6). Proteins with amino acid sequence identities $\geq 60 \%$ are grouped into subfamilies and denoted with a capital letter after the family number (e.g. OATP1A, OATP1B, OATP1C, OATP2A, OATP2B, etc.). Individual proteins (genes) are continuously numbered

cation/nomenclature system will be supported by the creation of an OATP/SLCO web site (http://www.kpt. unizh.ch/oatp/) and by the corresponding adaptation of the human (http://www.gene.ucl.ac.uk/nomenclature/) and mouse (http://www.informatics.jax.org) genome nomenclature databases as soon as possible. Furthermore, an expert committee, the members of which will be indicated on the OATP/SLCO web site, shall be created to help and supervise the future classification and nomenclature of newly identified members of the OATP/SLCO superfamily. We suggest starting with the new classification and nomenclature of the OATP/SLCO superfamily immediately and in close coordination with the adaptations of the human and mouse genome nomenclature databases. During the transition period, where the traditional (old) protein and gene names are still familiar to most investigators in the field, the new nomenclature should be supplemented by the familiar old names, which should be given in parentheses at the first occurrence in the text \{e.g. OATP1A2 [previously called OATP-A $(S L C 21 A 3)]\}$. This principle will also be adhered to in the following sections of this manuscript. according to the chronology of their identification. The "Oatp" (rodents)/"OATP" (human) symbols denote proteins, while the "Slco"/ "SLCO" symbols indicate the respective genes. Mouse Oatps are indicated by " $\mathrm{m}$ ". The tree was calculated using the ClustalW program (http://www.ebi.ac.uk/clustalw/) and visualized using the program TREVIEW [54]. Only the families OATP1 to OATP6 are indicated, since only these six families contain human OATPs (see also Fig. 3)

\section{History of discovery}

Rat Oatp1a1 [previously called Oatp1 (Slc21a1)] was the first member of the OATP/SLCO gene superfamily to be identified by expression cloning using the Xenopus laevis oocyte system [6]. Subsequently Oatp2a1 [previously called PGT (Slc2la2)] was identified by Kanai et al. [7]. OATP1A2 [previously called OATP-A (SLC21A3)] was the first human superfamily member isolated by hybridization screening from human liver [8]. Subsequently, additional Oatps/OATPs were identified and characterized from various species using homology screening either by hybridization experiments or in silico (Figs. 2, 3, Table 2).

\section{Molecular and phylogenetic relationships}

Oatps/OATPs represent 12 transmembrane domain (TM) proteins with common structural features such as (1) a large extracellular domain between TMs 9 and 10 (extracellular loop 5), which contains many conserved cysteine residues, (2) the $\mathrm{N}$-glycosylation sites in extracellular loops 2 and 5, and (3) the consensus superfamily 


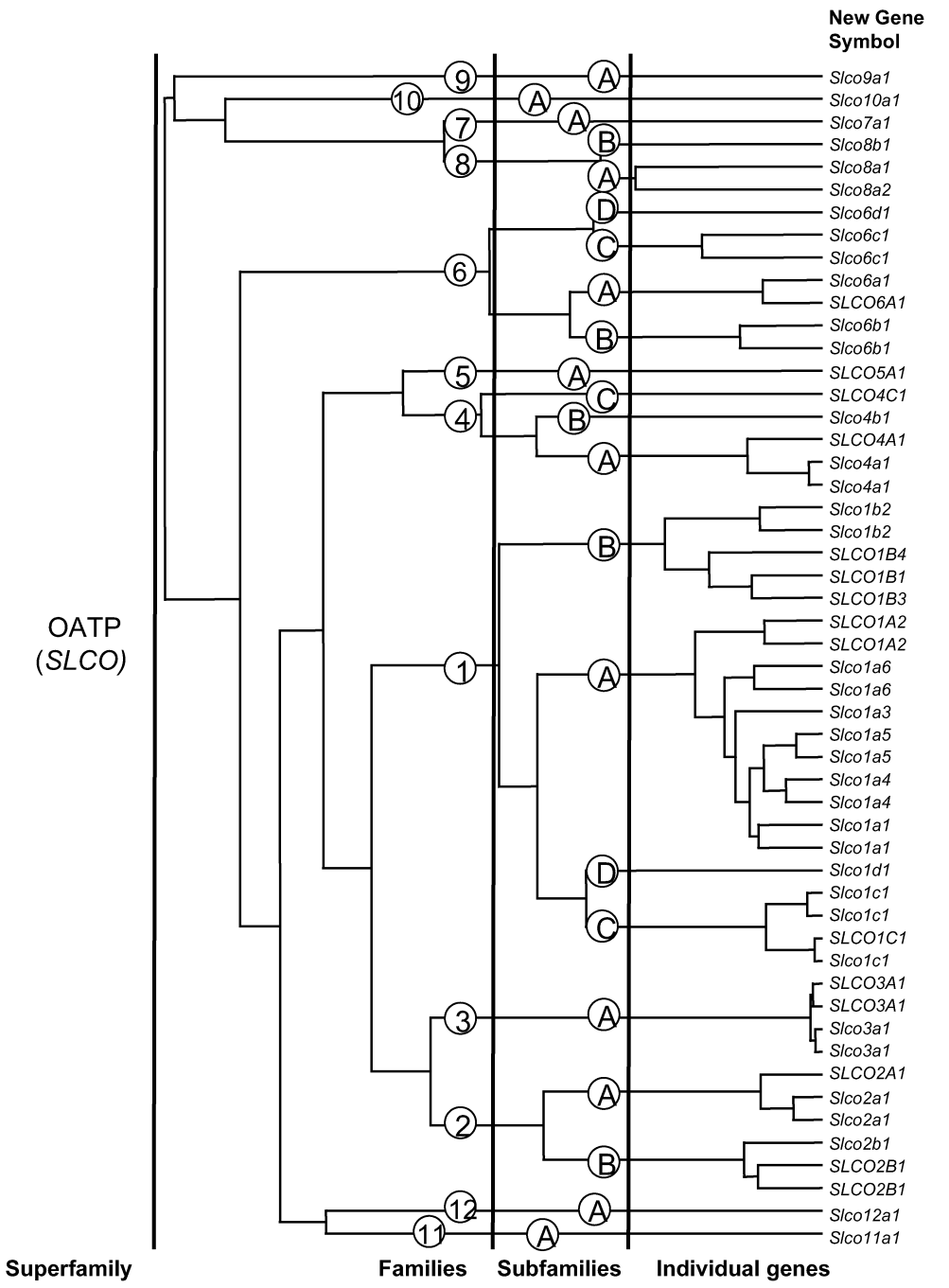

\begin{tabular}{|c|c|c|c|}
\hline $\begin{array}{l}\text { New Protein } \\
\text { Nomenclature }\end{array}$ & Species & $\begin{array}{l}\text { Old Protein } \\
\text { Nomenclature }\end{array}$ & $\begin{array}{l}\text { Old Gene } \\
\text { Symbols }\end{array}$ \\
\hline Oatp9a1 & C. elegans & CAB02665 & $F 21 G 4.1$ \\
\hline Oatp10a1 & D. melanogaster & AAF49332 & CG7571 \\
\hline Oatp7a1 & D. melanogaster & AAF53195 & CG5427 \\
\hline Oatp8b1 & D. melanogaster & AAF46826 & CG3380 \\
\hline Oatp8a1 & D. melanogaster & AAF46824 & CG3387 \\
\hline Oatp8a2 & D. melanogaster & AAF46825 & CG3382 \\
\hline Oatp6d1 & M. musculus & BAB29595 & \\
\hline Oatp6c1 & M. musculus & BAB30358 & \\
\hline Oatp6c1 & R. norvegicus & TST-2 & LOC287006 \\
\hline Oatp6a1 & M. fascicularis & BAB 69708 & \\
\hline OATP6A1 & H. sapiens & GST & \\
\hline Oatp6b1 & M. musculus & BAB24482 & \\
\hline Oatp6b1 & R. norvegicus & TST-1 & Tst-1 \\
\hline OATP5A1 & H. sapiens & OATP-J & SLC21A15 \\
\hline OATP4C1 & H. sapiens & OATP-H & SLC21A2O \\
\hline Oatp4b1 & D. melanogaster & AAG22418 & CG11332 \\
\hline OATP4A1 & H. sapiens & OATP-E & SLC21A12 \\
\hline Oatp4a1 & R. norvegicus & Oatp12 & S/c21a12 \\
\hline Oatp4a1 & M. musculus & Oatp12 & Slc21a12 \\
\hline Oatp1b2 & R. norvegicus & Oatp4 & Sc/21a10 \\
\hline Oatp1b2 & M. musculus & Oatp4 & Slc21a10 \\
\hline OATP1B4 & B. taurus & CAD48490 & OATP-C \\
\hline OATP1B1 & H. sapiens & OATP-C & $S L C 21 A 6$ \\
\hline OATP1B3 & H. sapiens & OATP8 & SLC21A8 \\
\hline OATP1A2 & H. sapiens & OATP-A & $S L C 21 A 3$ \\
\hline OATP1A2 & B. taurus & AAL14261 & $S L C 21 A 3$ \\
\hline Oatp1a6 & R. norvegicus & Oatp5 & Slc21a13 \\
\hline Oatp1a6 & M. musculus & Oatp5 & Slc21a13 \\
\hline Oatp1a3 & R. norvegicus & OAT-K1 & Slc21a4 \\
\hline Oatp1a5 & R. norvegicus & Oatp3 & Slc21a7 \\
\hline Oatp1a5 & M. musculus & Oatp3 & Slc21a7 \\
\hline Oatp1a4 & R. norvegicus & Oatp2 & SIc21a5 \\
\hline Oatp1a4 & M. musculus & Oatp2 & Slc21a5 \\
\hline Oatp1a1 & R. norvegicus & Oatp1 & Slc21a1 \\
\hline Oatp1a1 & M. musculus & Oatp1 & Slc21a1 \\
\hline Oatp1d1 & R. erinacea & AAL66021 & \\
\hline Oatp1c1 & R. norvegicus & Oatp14 & Slc21a14 \\
\hline Oatp1c1 & M. musculus & Oatp14 & Slc21a14 \\
\hline OATP1C1 & H. sapiens & OATP-F & SLC21A14 \\
\hline Oatp1c1 & M. fascicularis & BAB12153 & \\
\hline OATP3A1 & H. sapiens & OATP-D & SLC21A11 \\
\hline OATP $3 A 1$ & B. taurus & CAD48488 & OATP-D \\
\hline Oatp3a1 & R. norvegicus & Oatp11 & Slc21a11 \\
\hline Oatp3a1 & M. musculus & Oatp11 & Slc21a11 \\
\hline OATP2A 1 & H. sapiens & hPGT & SLC21A2 \\
\hline Oatp2a1 & R. norvegicus & rPGT & Slc21a2 \\
\hline Oatp2a1 & M. musculus & mPGT & Slc21a2 \\
\hline Oatp2b1 & R. norvegicus & Oatp9 & Slc21a9 \\
\hline OATP2B1 & H. sapiens & OATP-B & $S L C 21 A 9$ \\
\hline OATP2B1 & B. taurus & NP_777268 & $S L C 21 A 9$ \\
\hline Oatp12a1 & C. elegans & САन̄21751 & Y70G10A.3 \\
\hline Oatp11a1 & C. elegans & AAB52651 & F53B1.8 \\
\hline
\end{tabular}

Fig. 3 Phylogenetic classification and new nomenclature of 52 members of the OATP/SLCO superfamily of membrane transporters. The superfamily is grouped into families $(\geq 40 \%$ amino acid sequence identity) and subfamilies $(\geq 60 \%$ amino acid sequence identity) as described in the text. The new gene symbol of the superfamily is "Slco" (rodents)/"SLCO" (human). For protein nomenclature the "Oatp" (rodents)/"OATP" (human) symbol is used. The new nomenclature consists of (1) the superfamily designation OATP (SLCO) (human members) or Oatp (Slco) (rodent members), (2) the family number, (3) the subfamily letter (capital letters for human members, small letters for rodents), and (4) continuous Arabic numbering of individual proteins (genes) according to the chronology of identification. For comparison, the old (current) protein and gene nomenclature is also given.

signature D-X-RW-(I,V)-GAWW-X-G-(F,L)-L at the border between extracellular loop 3 and TM 6 [1]. Based on sequence similarities with EST and genomic database entries, Oatp/OATP-related proteins were identified in many different species other than in humans, rat and mouse, including fruitflies (Drosophila melanogaster), bees (Apis melifera), nematodes (Caenorhabditis elegans), sea urchins (Strongylocentrotus purpuratus), catfish (Ictalurus punctatus), zebrafish (Danio rerio), pufferfish (Fugu rubripes), frogs (Xenopus laevis), chick-
Superfamily members of human, rat, mouse, cow, Drosophila and $C$. elegans are given illustrating the species-independence of the new classification system. The phylogenetic tree was calculated using GCG programs PILEUP, DISTANCES and GROWTREE and visualized using the program TREEVIW [54]. Important remark: In comparison to our previously suggested classification [1] the families OATP6 and OATP10 have been exchanged (i.e. OATP6 $=$ previous OATP10; OATP10 = previous OATP6). By this change all families containing human OATPs are clustered within the families OATP1 to OATP6. Families OATP7 to OATP12 do not contain any human OATPs. It is suggested that in future this classification should be used rather than the previous one [1], since we feel that it is advantageous to group all human OATPcontaining families together

en (Gallus gallus), cow (Bos taurus) and pig (Sus scrofa). However, no similarities were found with the sequenced genomes of bacteria and yeast. With respect to the evolution of the animal kingdom, Oatps/OATPs were so far only found in animals that belong to the bilaterians, i.e. to species that belong to the clade of protostomia (e.g. arthropods, nematodes) or to the clade of deuterostomia (e.g. vertebrates, echinoderms). 


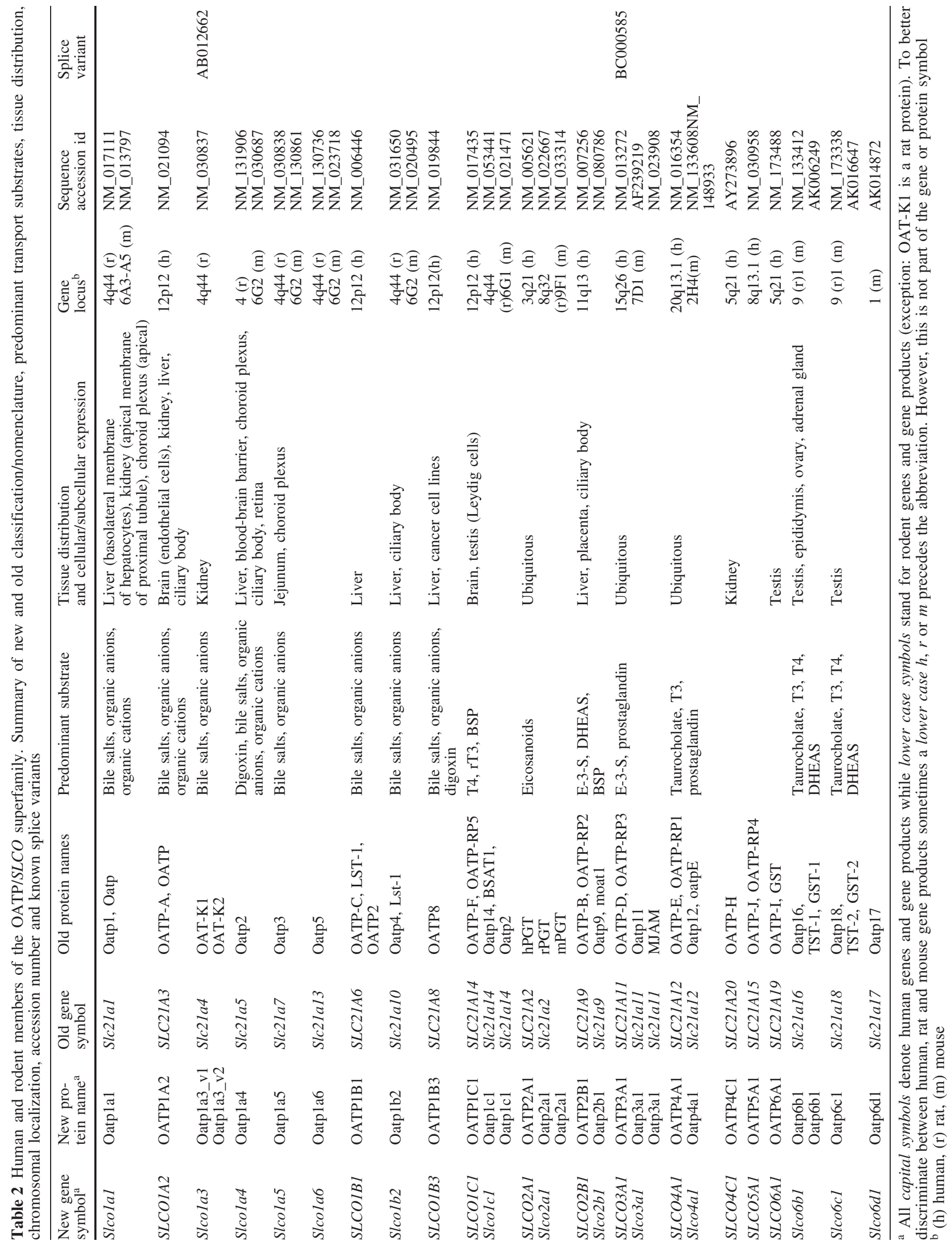




\section{Functional characteristics, physiological importance and pharmacological implications}

Oatps/OATPs are sodium-independent transport systems $[6,8,9,10]$. Their transport mechanism appears to be anion exchange, coupling the cellular uptake of organic compounds with the efflux of, for example, bicarbonate, glutathione and/or glutathione-S-conjugates $[11,12,13$, 14]. Although the latter has been demonstrated so far only for rat Oatp1a1 and Oatp1a4 [previously called Oatp2 (Slc21a5)], it is highly likely that all members of the OATP superfamily can mediate bidirectional organic substrate transport, making the overall directionality of transport dependent on the prevailing local substrate gradients. Oatp/OATP-mediated organic anion exchange seems to be $\mathrm{pH}$-dependent and electroneutral [12]. In addition, it has been demonstrated that the phosphorylation state of rat Oatpla1 is important for transport since extracellular ATP reduces Oatp1a1-mediated BSP transport in rat hepatocytes via phosphorylation at intracellular serine residues [15].

Most Oatps/OATPs transport a wide spectrum of amphipathic organic compounds. This broad substrate specificity was demonstrated first for rat Oatp1a1 [16]. Originally, Oatp1a1 was isolated as a sodium-independent bromosulfophthalein (BSP) and taurocholate uptake system of rat liver [6]. Subsequently, extensive functional characterization in different experimental systems established that it can mediate the transport of a wide range of amphipathic organic compounds including bile salts, steroid hormones and their conjugates, thyroid hormones, organic cations such as $N$-(4,4-azo- $n$-pentyl)-21-deoxyajmalinium and numerous drugs including the endothelin receptor antagonist BQ-123, the thrombin inhibitor CRC220, the opioid receptor agonists [D-penicillamine 2,5] enkephalin (DPDPE) and deltorphin II, the angiotensinconverting enzyme inhibitors enalapril and temocaprilat, the HMG-CoA reductase inhibitor pravastatin and the antihistamine fexofenadine [1]. Such a broad and partially overlapping substrate specificity has also been documented for most other members of the OATP1A- and OATP1B-subfamilies (Table 2) indicating that they play an important role, together with the P-glycoproteins (Mdrs/MDRs) and the multidrug resistance associated proteins (Mrps/MRPs), in overall drug absorption and drug disposition.

The broad substrate specificity of many Oatps/OATPs raises the question as to the common chemical and/or structural denominators of Oatp/OATP substrates. No systematic studies have been performed in this direction so far. However, from the available data it can be concluded that in general Oatp/OATP substrates are anionic amphipathic molecules with a rather high molecular weight $(>450)$ and a high degree of albumin binding under physiological conditions. Based on recent 3DQSAR studies a pharmacophore model containing two hydrogen bond acceptors, one hydrogen bond donor and two hydrophobic regions was obtained. These character- istics are met by most Oatp/OATP substrates including bile salts, steroids and cyclic and linear peptides.

Rifamycin SV and rifampicin are two structurally related antibiotics that have been shown to interact with Oatp/OATP-mediated transport. It turns out that rifamycin is a potent inhibitor of all human liver OATPs as well as of rat Oatp1a1 and Oatp1a4, while rifampicin mainly inhibits human OATP1B3 [previously called OATP8 (SLC21A8)] and rat Oatp1a4 [17, 18]. These data indicate that co-administration of a specific OATP-inhibitor could be used to increase the oral bioavailability of drugs that otherwise have a high OATP-mediated hepatic first-pass elimination. Hence, preferential or even selective inhibition of hepatic Oatps/OATPs has important implications for drug development and drug therapy.

Although some Oatps/OATPs are preferentially, or even selectively, expressed in the liver (e.g. Oatp1b2, OATP1B1, OATP1B3) (Fig. 4), many Oatps/OATPs exhibit multiple tissue expression (e.g. Oatp1a1, Oatp1a4, Oatp1a5, OATP1A2, OATP2B1) (Fig. 4, Table 2) [1]. As indicated in Fig. 4, all liver Oatps/OATPs are localized at the basolateral (sinusoidal) plasma membrane domain of hepatocytes. In contrast, in choroid plexus Oatp1a4 is localized basolaterally whereas Oatp1a1 and/or Oatp1a5 [previously called Oatp3 (Slc2la7)] is (are) localized at the apical plasma membrane (Fig. 4) [1]. In addition, Oatp1a1 and Oatp1a5 are also localized at the apical plasma membrane domains in renal proximal tubular and intestinal epithelial cells, respectively (Fig. 4). Hence, while Oatp1a1 appears to be differentially targeted in different epithelial cells, Oatp1a4 exhibits consistent basolateral, and Oatp1a3 [previously called OAT-K1 (Slc21a4)] and Oatp1a5 consistent apical, expression in polar epithelial cells (Fig. 4). The molecular targeting mechanisms for various Oatps/OATPs in distinct epithelial cells remain to be elucidated.

\section{Properties of individual human (and rodent) OATPs}

\section{Family OATP1}

Family OATP1 consists of four subfamilies, of which the three subfamilies OATP1A, OATP1B and OATP1C contain 17 individual genes in humans, rat and mouse (Figs. 2, 3).

\section{Subfamily OATP1A}

This subfamily contains a single human member, OATP1A2 (Figs. 2, 3, Table 2), which is a glycoprotein of 670 amino acids [8] and shares between 66 and $77 \%$ amino acid sequence identity with its rodent orthologs [1]. Although three different transcript variants encoding two different proteins are deposited in the database, only OATP1A2 with 670 amino acids has been functionally analyzed. The existence of the other two variants has been predicted only in silico. OATP1A2 was originally cloned 
Fig. 4 Distribution and polar expression of Oatps/OATPs in selected rat and human epithelial tissues. The Oatps/OATPs from the same subfamily are labelled with the same color unknown potential members are given in orange
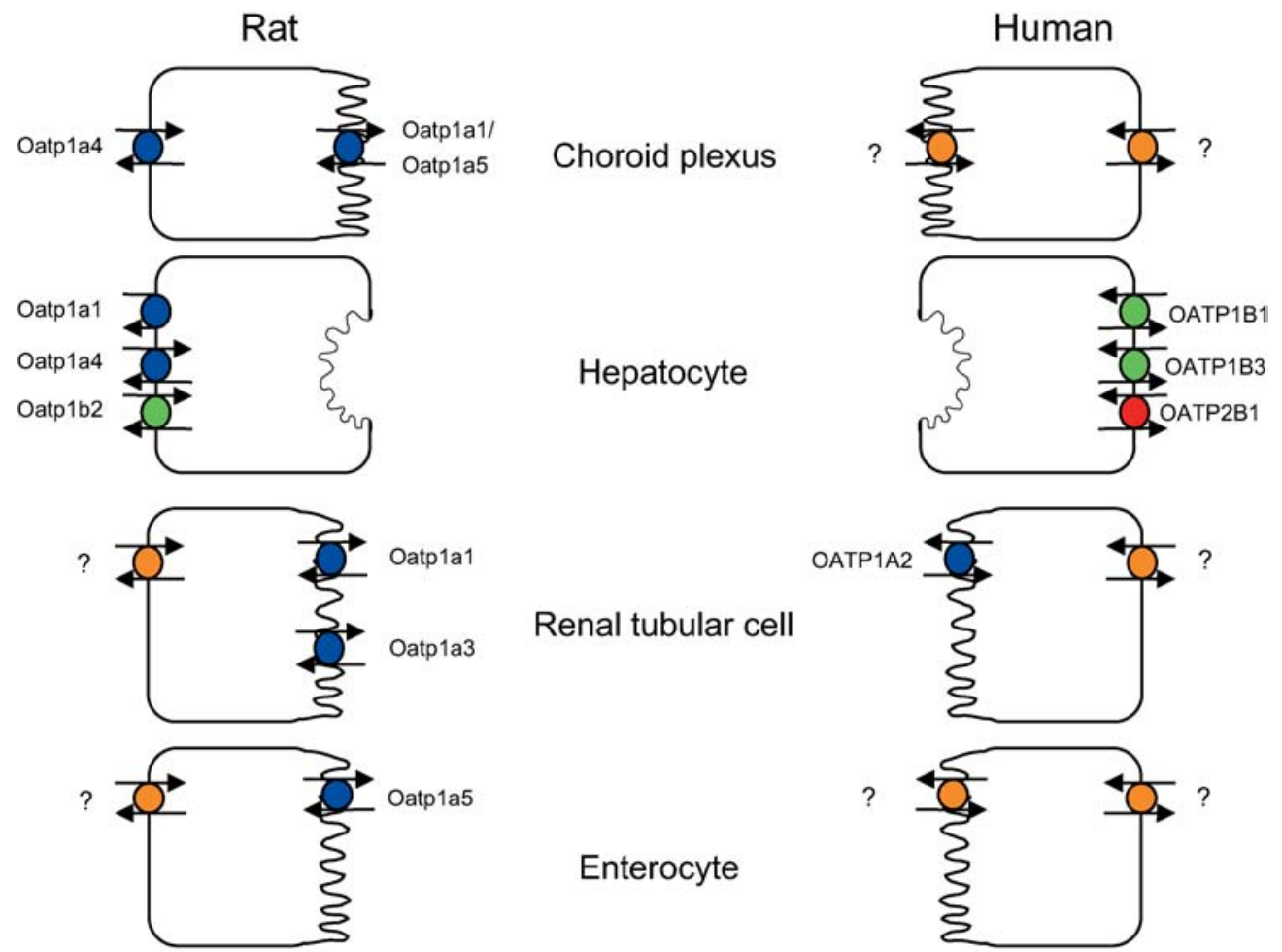

Iasolateral

apical

basolateral from a human liver cDNA library, but its strongest expression is in brain [8].

In addition, OATP1A2 is expressed in liver and colon cancer cells as well as in the human hepatoma cell line HepG2 [3, 19, 20]. In human liver, OATP1A2 exhibits an apparent molecular mass of approximately $85 \mathrm{kDa}$ [20], while in brain capillary endothelial cells (blood-brain barrier) its apparent molecular mass is $\sim 60 \mathrm{kDa}$ because of incomplete glycosylation [21].

Transport substrates of OATP1A2 include bile salts and BSP, steroid conjugates, the thyroid hormones T4, T3 and $\mathrm{rT} 3$, prostaglandin $\mathrm{E} 2$, the endothelin receptor antagonist BQ-123, the thrombin inhibitor CRC-220, the opioid receptor agonists DPDPE and deltorphin II, fexofenadine, certain magnetic resonance imaging contrast agents, ouabain, the lipophillic organic cations $\mathrm{N}$ (4,4-azo-n-pentyl)-21-ajmalinium, rocuronium and $N$ methyl-quinine and -quinidine and the cyanobacterial toxin microcystin [1]. Thus, human OATP1A2 transports the largest number of amphipathic substrates of all human OATPs [22]. Its expression at the blood-brain barrier suggests an important role for OATP1A2 in (1) the delivery of drugs and neuroactive peptides to the brain, and (2) the removal of organic metabolites from the brain.

Down-regulation of rodent Oatps has been demonstrated in several models of cholestatic liver diseases [23] and some of the transcriptional and post-transcriptional regulatory mechanisms have been investigated [1]. Interestingly, the expression of human OATP1A2 is maintained or even moderately increased in patients with primary sclerosing cholangitis [20] suggesting that its expression might be differently regulated at the transcriptional and post-transcriptional level as compared to other Oatps/ OATPs.

OATP1A2 has five rat (Oatp1a1 [6], Oatp1a3 [24], Oatp1a4 [9], Oatp1a5 [25], and Oatp1a6 [previously called Oatp5 (Slc21a13) (AF053317)] and four mouse (Oatp1a1 [26], Oatp1a4 [27], Oatp1a5 [10], Oatp1a6 [28]) homologs within the subfamily OATP1A (Figs. 2, 3, Table 2). As evidenced from their clustering on chromosomes 4 and 6 in rat and mouse, respectively, they arose through several gene duplications after divergence of the rodent species from man. Except for Oatp1a6, which so far seems to be an orphan transporter, all members of the OATP1A-subfamily have been characterized in great details at the functional level [1].

\section{Subfamily OATP1B}

This subfamily has two human members, OATP1B1 [previously called OATP-C (SLC21A6)], and OATP1B3 (Figs. 2, 3, Table 2). OATP1B1 was cloned from human liver [3, 29, 30, 31] and encodes a 691-amino-acid glycoprotein. It shares $80 \%$ amino acid identity with OATP1B3, but only 64\%/65\% identity with its rat/mouse ortholog Oatp1b2 [previously called Oatp4 (Slc21a10)] [1]. Expression of OATP1B1 appears to be restricted to the basolateral (sinusoidal) plasma membrane of hepatocytes [3, 29, 30, 31] (Fig. 4, Table 2). Its apparent molecular mass is $84 \mathrm{kDa}$, which is reduced after deglycosylation to $54 \mathrm{kDa}$ [31]. Its apparent exclusive 
expression in human liver suggests that OATP1B1 plays a crucial role in the hepatic clearance of albumin-bound amphipathic organic compounds.

The transport functions of OATP1B1 have been characterized in $X$. laevis oocytes $[22,30]$ and in stably transfected HEK-293 cells [3, 29, 31]. Its spectrum of transport substrates includes bile salts, conjugated and unconjugated bilirubin, BSP, steroid conjugates, the thyroid hormones T4 and T3, eicosanoids, cyclic peptides, drugs such as benzylpenicillin, methotrexate, pravastatin and rifampicin as well as the natural toxins microcystin and phalloidin [1]. Thus, OATP1B1 exhibits a similar wide substrate spectrum as the OATP1Asubfamily members.

Several polymorphisms in the SLCO1B1 (= gene symbol of OATP1B1; Figs. 2, 3, Table 2) gene have been described recently [32, 33]. A number of the identified SLCOIBI alleles were associated with a dramatic reduction of $V_{\max } / K_{\mathrm{m}}$ values indicating a significant decrease of OATP1B1-mediated transport function. The OATP1B1 variant OATP1B1-L193R has been shown to be associated with defects in protein maturation as well as in transport function [34]. Whether other polymorphisms of SLCOIBI also result in decreased OATP1B1 function in vivo and/or in additional phenotypic alterations remain to be investigated.

Transcriptional expression of OATP1B1 appears to be decreased in primary sclerosing cholangitis since these patients experience a decrease of mRNA levels to about $50 \%$ as compared to healthy control livers [35]. In addition, similar to Oatp1a1 and Oatp1a4, basal expression of human OATP1B1 is dependent on the liverenriched transcription factor HNF-1 $\alpha$ [36].

OATP1B3 (Figs. 2, 3, Table 2) was cloned from human liver and encodes a glycoprotein of 702 amino acids [37, 38]. It has an apparent molecular mass of $120 \mathrm{kDa}$, which is reduced after deglycosylation to $65 \mathrm{kDa}$ [38]. Under normal physiological conditions, OATP1B3 is predominantly, if not exclusively, expressed at the basolateral plasma membrane of hepatocytes [37, 38] (Fig. 4, Table 2). However, OATP1B3 has been shown to also be expressed in various human cancer tissues as well as in different tumor cell lines derived from gastric, colon, pancreas, gallbladder, lung and brain cancers [37]. The pathobiological significance of OATP1B3 expression in human cancer tissues remains to be investigated.

The spectrum of transport substrates of OATP1B3 was investigated in $X$. laevis oocytes and in stably transfected HEK-293 cells. It includes bile salts, monoglucuronosyl bilirubin, BSP, steroid conjugates, the thyroid hormones $\mathrm{T} 3$ and $\mathrm{T} 4$, leukotriene $\mathrm{C}_{4}$, linear and cyclic peptides, the cardiac glycosides digoxin and ouabain, the antineoplastic organic anion methothrexate, the antibiotic rifampicin and the natural toxins microcystin and phalloidin [1]. Thus, OATP1B3 has a similar broad substrate specificity as OATP1B1. However, OATP1B3 also exhibits unique transport properties such as, for example, for the intestinal peptide cholecystokinin 8 (CCK-8) [39], the opioid peptide deltorphin II [22] and the cardiac glycosides digoxin and ouabain [22].

Hepatic expression of OATP1B3 depends on HNF-1 $\alpha$ [36] as well as on the bile acid nuclear receptor FXR/ BAR [40]. The latter findings indicate that induction of SLCO1B3 gene expression by bile acids could serve to maintain hepatic extraction of xenobiotics and peptides under cholestatic conditions.

In rat and mouse the single ortholog Oatp1b2 [41, 42] has been identified for the two human OATP1B-subfamily members (Figs. 2, 3, Table 2). Thus, in contrast to the OATP1A-subfamily, gene duplication in the OATP1Bsubfamily occurred in man after divergence of the rodent species. Although Oatp1b2 is also mainly expressed in the liver and is functionally similar to human OATP1B 1 and OATP1B3 [1], our recent preliminary studies indicate that Oatp1b2 is expressed additionally in the ciliary body epithelium of the eye.

\section{Subfamily OATPIC}

This subfamily contains human OATP1C1 [previously called OATP-F (SLC21A14)] (Figs. 2, 3, Table 2), which was isolated from a human brain library [43] and represents a 712-amino-acid protein that exhibits $85 \%$ / $84 \%$ amino acid sequence identities with its rat/mouse ortholog Oatp1c1 [previously called Oatp14 (Slc21a14)]. These three genes form the OATP1C-subfamily (Figs. 2, 3 , Table 2). On the mRNA level OATP1C1 is expressed in brain and testis (Leydig cells) [43] (Table 2).

Although OATP1C1 belongs to the OATP1 family (Figs. 2, 3), the members of which are paradigmatic for their high degree of multispecificity, the substrate spectrum of OATP1C1 is rather limited [43]. While some substrates such as BSP, estradiol-17 $\beta$-glucuronide, estrone-3-sulfate and the thyroid hormone $\mathrm{T} 3$ are transported to some extent, OATP1C1 exerts an especially high transport affinity for T4 (thyroxine) $(K \mathrm{~m}$ value $\sim 90 \mathrm{nM})$ and rT3 (reverse tri-iodothyronine) (Km value $\sim 130 \mathrm{nM}$ ). Hence, it might play an important role in the delivery and disposition of thyroid hormones in brain and testis, and thus during brain development.

Rat Oatp1c1 has been isolated from a cDNA library enriched in mRNAs specific to the blood-brain barrier [44]. Nothing is known so far about the function and regulation of this putative organic anion transporter. Interestingly, however, mouse Oatp1c1 has been isolated from a cochlea cDNA library (accession number NM_021471) indicating that it might play a physiological role in the inner ear.

\section{Family OATP2}

Family OATP2 consists of the two subfamilies OATP2A and OATP2B with a total of five individual genes in man, rat and mouse (Figs. 2, 3). 


\section{Subfamily OATP2A}

This subfamily contains human OATP2A1 [previously called PGT (SLC21A2)] (Figs. 2, 3, Table 2), which is a protein of 643 amino acids that shares $82 \% / 83 \%$ amino acid sequence identities with its rat/mouse orthologs [1]. Although OATP2A1 has been cloned from a kidney library [45], its mRNA is ubiquitously expressed with highest levels in heart, skeletal muscle and pancreas. Neither the protein expression nor its transcriptional and/ or post-transcriptional regulations have been studied in any detail. On the functional level, OATP2A1 has been characterized in transiently transfected HeLa cells, where it transported different prostaglandins and thromboxane $\mathrm{B}_{2}$. Human OATP2A1 has the single ortholog Oatp2a1 in rat [7] and mouse [46] (Figs. 2, 3, Table 2).

\section{Subfamily OATP2B}

This subfamily contains human OATP2B1 [previously called OATP-B (SLC21A9)] (Figs. 2, 3, Table 2), which was originally isolated from human brain as a 709-aminoacid protein [47]. It shows a $77 \%$ amino acid sequence identity with its rat ortholog Oatp2b1 [previously called Oatp9 (Slc21a9)] [1]. Although human OATP2B1 was originally cloned from a brain library, its strongest expression is in the liver, followed by the spleen, placenta, lung, kidney, heart, ovary, small intestine, and brain $[3,22,48]$. In addition, OATP2B1 is expressed in several fetal tissues and in colon adenocarcinoma (CX-1) cells [3]. In human liver, OATP2B1 is exclusively expressed at the basolateral (sinusoidal) plasma membrane of hepatocytes and exhibits an apparent molecular mass of $85 \mathrm{kDa}$ [22]. Thus, besides OATP1B1 and OATP1B3, OATP2B1 is the third OATP localized at the sinusoidal membrane of human hepatocytes (Fig. 4).

Functionally, OATP2B1 has been studied in X. laevis oocytes and in transiently transfected HEK293 cells [3, 22]. Compared to other OATPs it has a narrow substrate specificity and transports only BSP, estrone-3-sulfate and dehydroepiandrosterone-sulfate (DHEAS). For other compounds such as $\mathrm{PGE}_{2}$ and estradiol-17 $\beta$-glucuronide controversial results have been presented [1].

Oatp2b1 [49] is the single ortholog of human OATP2B1 and has been isolated as a multispecific organic anion transporter from rat brain with similar function as but broader substrate specificity than OATP2B1 [1].

\section{Family OATP3}

Family OATP 3 consists of a single subfamily (OATP3A) with a total number of three highly homologous individual genes in man, rat and mouse (Figs. 2, 3).

\section{Subfamily OATP3A}

This subfamily contains human OATP3A1 [previously called OATP-D (SLC21A11)] (Figs. 2, 3, Table 2), which has been isolated from a human kidney library as a 710amino-acid protein [3]. At the amino acid level, OATP3A1 shows a $97 \%$ sequence identity with its rat and mouse ortholog Oatp3a1 [previously called Oatp11 (Slc21a11)] [1]. Thus, the OATP3A subfamily has been highly conserved during evolution, which is also documented by the highly homologous ortholog found in $B$. taurus (Fig. 3) and by several highly conserved sequences obtained when searching the genome databases of various species. Based on RT-PCR experiments, OATP3A1 is ubiquitously expressed and has also been detected in several cancer cell lines [3]. Thus, on the basis of mRNA expression OATP3A1 exhibits the widest tissue distribution of all OATPs so far investigated.

The functional transport properties of OATP3A1 have not been studied extensively. In HEK293 cells transiently expressing OATP3A1, only estrone-3-sulfate, $\mathrm{PGE}_{2}$ and benzylpenicillin have been identified as substrates [3]. Despite this limited characterization of its transport properties, the high degree of amino acid identities within this subfamily as well as the wide tissue distribution of OATP3A1 indicate that these gene products might serve an important physiologic function. A splice variant with a different C-terminal end (OATP3A1_v2) has been deposited in the database (BC000585, Table 2), however, no functional data are available so far.

Rat and mouse Oatp3a1 have so far only been identified and deposited in the database as cDNAs encoding 710-amino-acid proteins (accession numbers: rat: AF239219; mouse: AF226324).

\section{Family OATP4}

Family OATP4 consists of three subfamilies, of which the two subfamilies OATP4A and OATP4C contain four individual genes in man, rat and mouse (Figs. 2, 3).

\section{OATP4A}

This subfamily contains human OATP4A1 [previously called OATP-E (SLC21A12)] (Figs. 2, 3, Table 2), which was isolated from human kidney and brain as a 722 amino-acid protein $[3,50]$. It shows $76 \%$ amino acid sequence identity with its rodent ortholog Oatp4a1 [previously called Oatp12 (Slc21a12)] (Figs. 2, 3, Table 2). OATP4A1 mRNA is expressed ubiquitously with strongest expression in liver, heart, placenta and pancreas [50]. At the protein level it has been localized to the apical surface of the syncytiotrophoblast [51].

In cRNA-injected $X$. laevis oocytes OATP4A1 transported taurocholate and the thyroid hormones T3, T4 and rT3 [50], while in transiently transfected HEK293 cells 
additional uptake of steroid conjugates, $\mathrm{PGE}_{2}$ and benzylpenicillin was found [3].

Oatp4a1 [50] was isolated from a rat retina cDNA library as a 722-amino-acid protein and has so far only been characterized minimally. It seems to mediate transport of taurocholate, T3 and $\mathrm{PGE}_{2}[50]$.

\section{Subfamily OATP4C}

This subfamily contains human OATP4C1 [previously called OATP-H (SLC21A20)] (Figs. 2, 3, Table 2), which is so far the only $S L C O$ gene in this subfamily. Its cDNA sequence has been deposited in the database. Its functional properties are currently under investigation in our laboratory.

\section{Family OATP5}

Family OATP5 consists of the single subfamily OATP5A with a single human gene (Figs. 2, 3).

\section{Subfamily OATP5A}

This subfamily contains human OATP5A1 [previously called OATP-J (SLC21A15)] (Figs. 2, 3, Table 2), which has been isolated and deposited in the database (NM_030958) as a cDNA encoding a protein of 848 amino acids with unknown transport properties.

\section{Family OATP6}

Family OATP6 consists of the four subfamilies OATP6A, OATP6B, OATP6C and OATP6D, which contain six individual genes in man, rat and mouse (Figs. 2, 3). Please note that this family has previously been classified as OATP10 [1].

\section{Subfamily OATP6A}

This subfamily contains human OATP6A1 [previously called OATP-I (SLC21A19)] (Figs. 2, 3, Table 2), which has been isolated from human testis but so far no functional characterization has been published [52].

\section{Subfamily OATP6B}

This subfamily contains rat and mouse Oatp6b1 [previously called GST-1 (Slc21a16)] (Figs. 2, 3, Table 2). Rat Oatp6b1 has recently been published to be a gonadspecific transport system for taurocholate, DHEAS and thyroxine [52]. Mouse Oatp6b1 has been identified as an OATP-related protein with no functional characterization so far [53].
Subfamily OATP6C

This subfamily contains the rat gonad-specific organic anion transporter Oatp6c1 [previously called GST-2 (Slc21a18)] (Figs. 2, 3, Table 2) [52]. Mouse Oatp6c1 has been identified as an OATP-related protein with no functional characterization so far [53].

\section{Subfamily OATP6D}

This subfamily contains a single mouse Oatp6d1 [previously called Oatp17 (Slc21a17)] (Figs. 2, 3, Table 2) that was identified as an OATP-related protein with no functional characterization so far [53].

\section{Conclusions and perspectives}

The OATP/SLCO superfamily consists of multi- and oligospecific membrane transport systems, that mediate sodium-independent transmembrane solute transport. The multispecific transporters accept a broad range of amphipathic endo- and xenobiotics. Their multiple expression in the liver, kidney, small intestine, choroid plexus, bloodbrain barrier and many other tissue barriers puts them into a strategic position for absorption, distribution and excretion of xenobiotic substances. Thus, multispecific Oatps/OATPs are important transporters of the overall body detoxification system. Alternatively, Oatps/OATPs with a rather restricted substrate specificity appear to be more highly conserved during evolution, exhibit a narrower tissue distribution, and might have important physiological functions in specific organs.

Although several individual members of the OATP/ $S L C O$ superfamily have been characterized in detail, numerous questions remain unanswered and require more thorough investigations in the near future. They include: (1) the determination of the exact tissue expression of all individual Oatps/OATPs, (2) the definitive characterization of the driving force(s) involved in Oatp/OATPmediated substrate transport, (3) a detailed understanding of the molecular basis of the broad substrate specificity, (4) the development of specific inhibitors for individual Oatps/OATPs, (5) investigation of the transcriptional and post-transcriptional regulation of individual Oatp/OATP expression, (6) elucidation of interactions of Oatps/ OATPs with other proteins, (7) identification and characterization of gene polymorphisms, and (8) determination of the overall significance of individual Oatps/ OATPs for physiology, pathophysiology, pharmacology and toxicology.

Acknowledgements The authors were supported by the Swiss National Science Foundation (grants 31-59204.99 to B.H. and 3164140.00 to P.J.M.). 


\section{References}

1. Hagenbuch B, Meier PJ (2003) The superfamily of organic anion transporting polypeptides. Biochim Biophys Acta 1609:1-18

2. Meier PJ, Stieger B (2002) Bile salt transporters. Annu Rev Physiol 64:635-661

3. Tamai I, Nezu J, Uchino H, Sai Y, Oku A, Shimane M, Tsuji A (2000) Molecular identification and characterization of novel members of the human organic anion transporter (OATP) family. Biochem Biophys Res Commun 273:251-260

4. Nelson DR, Koymans L, Kamataki T, Stegeman JJ, Feyereisen R, Waxman DJ, Waterman MR, Gotoh O, Coon MJ, Estabrook RW, Gunsalus IC, Nebert DW (1996) P450 superfamily: update on new sequences, gene mapping, accession numbers and nomenclature. Pharmacogenetics 6:1-42

5. Mackenzie PI, Owens IS, Burchell B, Bock KW, Bairoch A, Bélanger A, Fournel-Gigleux S, Green M, Hum DW, Iyanagi T, Lancet D, Louisot P, Magdalou J, Roy Chowdhury J, Ritter JK, Schachter H, Tephly TR, Tipton KF, Nebert DW (1997) The UDP glycosyltransferase gene superfamily: recommended nomenclature update based on evolutionary divergence. Pharmacogenetics 7:255-269

6. Jacquemin E, Hagenbuch B, Stieger B, Wolkoff AW, Meier PJ (1994) Expression cloning of a rat liver $\mathrm{Na}^{+}$-independent organic anion transporter. Proc Natl Acad Sci USA 91:133-137

7. Kanai N, Lu R, Satriano JA, Bao Y, Wolkoff AW, Schuster VL (1995) Identification and characterization of a prostaglandin transporter. Science 268:866-869

8. Kullak-Ublick GA, Hagenbuch B, Stieger B, Schteingart CD, Hofmann AF, Wolkoff AW, Meier PJ (1995) Molecular and functional characterization of an organic anion transporting polypeptide cloned from human liver. Gastroenterology 109:1274-1282

9. Noé B, Hagenbuch B, Stieger B, Meier PJ (1997) Isolation of a multispecific organic anion and cardiac glycoside transporter from rat brain. Proc Natl Acad Sci USA 94:10346-10350

10. Walters HC, Craddock AL, Fusegawa H, Willingham MC, Dawson PA (2000) Expression, transport properties, and chromosomal location of organic anion transporter subtype 3. Am J Physiol 279:G1188-G1200

11. Shi XY, Bai S, Ford AC, Burk RD, Jacquemin E, Hagenbuch B, Meier PJ, Wolkoff AW (1995) Stable inducible expression of a functional rat liver organic anion transport protein in HeLa cells. J Biol Chem 270:25591-25595

12. Satlin LM, Amin V, Wolkoff AW (1997) Organic anion transporting polypeptide mediates organic anion/HCO3- exchange. J Biol Chem 272:26340-26345

13. Li L, Meier PJ, Ballatori N (2000) Oatp2 mediates bidirectional organic solute transport: a role for intracellular glutathione. Mol Pharmacol 58:335-340

14. Li LQ, Lee TK, Meier PJ, Ballatori N (1998) Identification of glutathione as a driving force and leukotriene C-4 as a substrate for oatp1, the hepatic sinusoidal organic solute transporter. J Biol Chem 273:16184-16191

15. Glavy JS, Wu SM, Wang PJ, Orr GA, Wolkoff AW (2000) Down-regulation by extracellular ATP of rat hepatocyte organic anion transport is mediated by serine phosophorylation of Oatp1. J Biol Chem 275:1479-1484

16. Bossuyt X, Muller M, Hagenbuch B, Meier PJ (1996) Polyspecific drug and steroid clearance by an organic anion transporter of mammalian liver. J Pharmacol Exp Ther 276:891-896

17. Fattinger K, Cattori V, Hagenbuch B, Meier PJ, Stieger B (2000) Rifamycin SV and rifampicin exhibit differential inhibition of the hepatic rat organic anion transporting polypeptides, Oatp1 and Oatp2. Hepatology 32:82-86

18. Vavricka SR, van Montfoort J, Ha HR, Meier PJ, Fattinger K (2002) Interactions of rifamycin SV and rifampicin with organic anion uptake systems of human liver. Hepatology $36: 164-172$
19. Lee TK, Hammond CL, Ballatori N (2001) Intracellular glutathione regulates taurocholate transport in HepG2 cells. Toxicol Appl Pharmacol 174:207-215

20. Kullak-Ublick GA, Glasa J, Boker C, Oswald M, Grutzner U, Hagenbuch B, Stieger B, Meier PJ, Beuers U, Kramer W, Wess G, Paumgartner G (1997) Chlorambucil-taurocholate is transported by bile acid carriers expressed in human hepatocellular carcinomas. Gastroenterology 113:1295-1305

21. Gao B, Hagenbuch B, Kullak-Ublick GA, Benke D, Aguzzi A, Meier PJ (2000) Organic anion-transporting polypeptides mediate transport of opioid peptides across blood-brain barrier. J Pharmacol Exp Ther 294:73-79

22. Kullak-Ublick GA, Ismair MG, Stieger B, Landmann L, Huber R, Pizzagalli F, Fattinger K, Meier PJ, Hagenbuch B (2001) Organic anion-transporting polypeptide B (OATP-B) and its functional comparison with three other OATPs of human liver. Gastroenterology 120:525-533

23. Lee J, Boyer JL (2000) Molecular alterations in hepatocyte transport mechanisms in acquired cholestatic liver disorders. Semin Liver Dis 20:373-384

24. Saito H, Masuda S, Inui K (1996) Cloning and functional characterization of a novel rat organic anion transporter mediating basolateral uptake of methotrexate in the kidney. J Biol Chem 271:20719-20725

25. Abe T, Kakyo M, Sakagami H, Tokui T, Nishio T, Tanemoto M, Nomura H, Hebert SC, Masuno S, Kondo H, Yawo H (1998) Molecular characterization and tissue distribution of a new organic anion transporter subtype (oatp3) that transports thyroid hormones and taurocholate and comparison with oatp2. J Biol Chem 273:22395-22401

26. Hagenbuch B, Adler ID, Schmid TE (2000) Molecular cloning and functional characterisation of the mouse organic anion transporting polypeptide 1 (Oatp1) and mapping of the gene to chromosome X. Biochem J 345:115-120

27. van Montfoort J, Schmid TE, Adler ID, Meier PJ, Hagenbuch B (2002) Functional characterization of the mouse organic anion transporting polypeptide 2. Biochim Biophys Acta 1564:183188

28. Choudhuri S, Ogura K, Klaassen CD (2001) Cloning, expression, and ontogeny of mouse organic anion-transporting polypeptide-5, a kidney specific organic anion transporter. Biochem Biophys Res Commun 280:92-98

29. Hsiang B, Zhu Y, Wang Z, Wu Y, Sasseville V, Yang W-P, Kirchgessner TG (1999) A novel human hepatic organic anion transporting polypeptide (OATP2). J Biol Chem 274:3716137168

30. Abe T, Kakyo M, Tokui T, Nakagomi R, Nishio T, Nakai D, Nomura H, Unno M, Suzuki M, Naitoh T, Matsuno S, Yawo H (1999) Identification of a novel gene family encoding human liver-specific organic anion transporter LST-1. J Biol Chem 274:17159-17163

31. König J, Cui Y, Nies AT, Keppler D (2000) A novel human organic anion transporting polypeptide localized to the basolateral hepatocyte membrane. Am J Physiol 278:G156-G164

32. Tirona RG, Leake BF, Merino G, Kim RB (2001) Polymorphisms in OATP-C: identification of multiple allelic variants associated with altered transport activity among European- and African-Americans. J Biol Chem 276:35669-35675

33. Nozawa T, Nakajima M, Tamai I, Noda K, Nezu J, Sai Y, Tsuji A, Yokoi T (2002) Genetic polymorphisms of human organic anion transporters OATP-C (SLC21A6) and OATP-B (SLC21A9): allele frequencies in the Japanese population and functional analysis. J Pharmacol Exp Ther 302:804-813

34. Michalski C, Cui Y, Nies AT, Nuessler AK, Neuhaus P, Zanger UM, Klein K, Eichelbaum M, Keppler D, Konig J (2002) A naturally occurring mutation in the SLC21A6 gene causing impaired membrane localization of the hepatocyte uptake transporter. J Biol Chem 277:43058-43063

35. Oswald M, Kullak-Ublick GA, Paumgartner G, Beuers U (2001) Expression of hepatic transporters OATP-C and MRP2 in primary sclerosing cholangitis. Liver 21:247-253 
36. Jung D, Hagenbuch B, Gresh L, Pontoglio M, Meier PJ, KullakUblick GA (2001) Characterization of the human OATP-C (SLC21A6) gene promoter and regulation of liver-specific OATP genes by hepatocyte nuclear factor 1 alpha. J Biol Chem 276:37206-37214

37. Abe T, Unno M, Onogawa T, Tokui T, Kondo TN, Nakagomi R, Adachi H, Fujiwara K, Okabe M, Suzuki T, Nunoki K, Sato E, Kakyo M, Nishio T, Sugita J, Asano N, Tanemoto M, Seki M, Date F, Ono K, Kondo Y, Shiiba K, Suzuki M, Ohtani H, Shimosegawa T, Iinuma, Nagura H, Ito S, Matsuno S (2001) LST-2, a human liver-specific organic anion transporter, determines methotrexate sensitivity in gastrointestinal cancers. Gastroenterology 120:1689-1699

38. König J, Cui Y, Nies AT, Keppler D (2000) Localization and genomic organization of a new hepatocellular organic anion transporting polypeptide. J Biol Chem 275:23161-23168

39. Ismair MG, Stieger B, Cattori V, Hagenbuch B, Fried M, Meier PJ, Kullak-Ublick GA (2001) Hepatic uptake of cholecystokinin octapeptide by organic anion-transporting polypeptides OATP4 and OATP8 of rat and human liver. Gastroenterology 121:1185-1190

40. Jung D, Podvinec M, Meyer UA, Mangelsdorf DJ, Fried M, Meier PJ, Kullak-Ublick GA (2002) Human organic anion transporting polypeptide OATP8 (SLC21A8) promoter is transactivated by the farnesoid $\mathrm{X}$ receptor/bile acid receptor. Gastroenterology 122:1954-1966

41. Cattori V, Hagenbuch B, Hagenbuch N, Stieger B, Ha R, Winterhalter KE, Meier PJ (2000) Identification of organic anion transporting polypeptide 4 (Oatp4) as a major full-length isoform of the liver-specific transporter-1 (rlst-1) in rat liver. FEBS Lett 474:242-245

42. Ogura K, Choudhuri S, Klaassen CD (2000) Full-length cDNA cloning and genomic organization of the mouse liver-specific organic anion transporter-1 (lst-1). Biochem Biophys Res Commun 272:563-570

43. Pizzagalli F, Hagenbuch B, Stieger B, Klenk U, Folkers G, Meier PJ (2002) Identification of a novel human organic anion transporting polypeptide (OATP-F) as a high affinity thyroxine transporter. Mol Endocrinol 16:2283-2296

44. Li JY, Boado RJ, Pardridge WM (2001) Blood-brain barrier genomics. J Cereb Blood Flow Metab 21:61-68

45. Lu R, Kanai N, Bao Y, Schuster VL (1996) Cloning, in vitro expression, and tissue distribution of a human prostaglandin transporter cDNA (HPGT). J Clin Invest 98:1142-1149

46. Pucci ML, Bao Y, Chan B, Itoh S, Lu R, Copeland NG, Gilbert DJ, Jenkins NA, Schuster VL (1999) Cloning of mouse prostaglandin transporter PGT cDNA: species-specific substrate affinities. Am J Physiol 299:R734-R741

47. Nagase T, Ishikawa K, Suyama M, Kikuno R, Hirosawa M, Miyajima N, Tanaka A, Kotani H, Nomura N, Ohara O (1998) Prediction of the coding sequences of unidentified human genes. XII. The complete sequences of 100 new cDNA clones from brain which code for large proteins in vitro. DNA Res $5: 355-364$
48. St-Pierre MV, Ugele B, Hagenbuch B, Meier PJ, Stallmach T (2002) Characterization of an organic anion transporting polypeptide (OATP-B) in human placenta. J Clin Endocrin Metabol 87:1856-1863

49. Nishio T, Adachi H, Nakagomi R, Tokui T, Sato E, Tanemoto M, Fujiwara K, Okabe M, Onogawa T, Suzuki T, Nakai D, Shiiba K, Suzuki M, Ohtani H, Kondo Y, Unno M, Ito S, Iinuma K, Nunoki K, Matsuno S, Abe T (2000) Molecular identification of a rat novel organic anion transporter moat1, which transports prostaglandin $\mathrm{D}(2)$, leukotriene $\mathrm{C}(4)$, and taurocholate. Biochem Biophys Res Commun 275:831-838

50. Fujiwara K, Adachi H, Nishio T, Unno M, Tokui T, Okabe M, Onogawa T, Suzuki T, Asano N, Tanemoto M, Seki M, Shiiba K, Suzuki M, Kondo Y, Nunoki K, Shimosegawa T, Iinuma K, Ito S, Matsuno S, Abe T (2001) Identification of thyroid hormone transporters in humans: different molecules are involved in a tissue-specific manner. Endocrinology 142:2005-2012

51. Sato K, Sugawara J, Sato T, Mizutamari H, Suzuki T, Ito A, Mikkaichi T, Onogawa T, Tanemoto M, Unno M, Abe T, Okamura K (2003) Expression of organic anion transporting polypeptide E (OATP-E) in human placenta. Placenta 24:144148

52. Suzuki T, Onogawa T, Asano N, Mizutamari H, Mikkaichi T, Tanemoto M, Abe M, Satoh F, Unno M, Nunoki K, Suzuki M, Hishinuma T, Goto J, Shimosegawa T, Matsuno S, Ito S, Abe T (2003) Identification and characterization of novel rat and human gonad specific organic anion transporters. Mol Endocrinol 3:3

53. Kawai J, Shinagawa A, Shibata K, Yoshino M, Itoh M, Ishii Y, Arakawa T, Hara A, Fukunishi Y, Konno H, Adachi J, Fukuda S, Aizawa K, Izawa M, Nishi K, Kiyosawa H, Kondo S, Yamanaka I, Saito T, Okazaki Y, Gojobori T, Bono $\mathrm{H}$, Kasukawa T, Saito R, Kadota K, Matsuda H, Ashburner M, Batalov S, Casavant T, Fleischmann W, Gaasterland T, Gissi C, King B, Kochiwa H, Kuehl P, Lewis S, Matsuo Y, Nikaido I, Pesole G, Quackenbush J, Schriml LM, Staubli F, Suzuki R, Tomita M, Wagner L, Washio T, Sakai K, Okido T, Furuno M, Aono H, Baldarelli R, Barsh G, Blake J, Boffelli D, Bojunga N, Carninci P, de Bonaldo MF, Brownstein MJ, Bult C, Fletcher C, Fujita M, Gariboldi M, Gustincich S, Hill D, Hofmann M, Hume DA, Kamiya M, Lee NH, Lyons P, Marchionni L, Mashima J, Mazzarelli J, Mombaerts P, Nordone P, Ring B, Ringwald M, Rodriguez I, Sakamoto N, Sasaki H, Sato K, Schonbach C, Seya T, Shibata Y, Storch KF, Suzuki H, Toyooka K, Wang KH, Weitz C, Whittaker C, Wilming L, Wynshaw-Boris A, Yoshida K, Hasegawa Y, Kawaji $\mathrm{H}$, Kohtsuki S, Hayashizaki Y (2001) Functional annotation of a full-length mouse cDNA collection. Nature 409:685-690

54. Page RDM (1996) TREEVIW: an application to display phylogenetic trees on personal computers. Comput Appl Biosci $12: 357-358$ 